Creative Commons User License: CC BY-NC-ND

Abstracted by: EBSCOhost, Electronic Journals Service (EJS), Google Scholar, Journal Seek, Scientific Commons,

Food and Agricultural Organization (FAO), CABI and Scopus

http://eoi.citefactor.org/10.11226/v24i3
Journal of Agricultural Extension

Vol. 24 (3) July, 2020

ISSN(e): 24086851; ISSN(Print); 1119944X

http://journal.aesonnigeria.org

http://www.ajol.info/index.php/iae

Email: editorinchief@aesonnigeria.org

\title{
Marketing Information Needs and Seeking Behaviour of Smallholder Livestock Farmers in the Eastern Cape Province, South Africa
}

https://dx.doi.org/10.4314/jae.v24i3.9

\author{
Nwafor, Christopher Ugochukwu \\ Central University of Technology, Free State, South Africa \\ Email: cnwafor@cut.ac.za. \\ Phone: +27515073355
}

\section{Ogundeji, Abiodun A}

University of the Free State, Bloemfontein, South Africa

Email:ogundejiaa@ufs.ac.za

Phone: +2754013352

\section{van der Westhuizen, Carlu}

Central University of Technology, Free State, South Africa

Email:cvdwesth@cut.ac.za

Phone: +27515073788

\section{Abstract}

This study examined marketing information needs and seeking behaviour among smallholder livestock farmers from the Eastern Cape province in South Africa. Structured questionnaires were used to collect data from 150 livestock farmers and analysed using percentages, weighted means for ranking and correlation. The results show a dominance of market price information requirement among farmers (65\%), immediate market price information need (38\%), high level of need (48\%), and a strong reliance on sources such as other farmers (36\%), phone calls (24\%) and auctions (23\%) for market information. In addition to this, the listed demographic characteristics of farmers namely age, sex, education, marital status, household size, income and herd size strongly influenced their information seeking behaviour $(p<0.05)$. Provision of additional sources of market price information, and ensuring that the personal features of farmers are taken into consideration when designing information service interventions is crucial.

Keywords: behaviour, information need, information-seeking, livestock farmer, smallholder

\section{Introduction}

The importance of accurate, timely and reliable information in diverse human activities has been emphasized by a number of scholars such as Gamble, Cassenti and Buchler (2018), Shah (2017) as well as Acheampong, Frimpong, Adu-Appiah and Asante (2017). Information empowers both individuals and their communities, and is a prerequisite for increased social equality and economic prosperity (Garrido 
Creative Commons User License: CC BY-NC-ND

Abstracted by: EBSCOhost, Electronic Journals Service (EJS), Google Scholar, Journal Seek, Scientific Commons,

Food and Agricultural Organization (FAO), CABI and Scopus
Journal of Agricultural Extension

Vol. 24 (3) July, 2020

ISSN(e): 24086851; ISSN(Print); 1119944X

http://journal.aesonnigeria.org

http://www.ajol.info/index.php/jae

Email: editorinchief@aesonnigeria.org

and Wyber, 2017). Understanding the specific information needed by farmers is necessary for achieving the goal of poverty alleviation through improved productivity and market participation. Farmers have been noted to apply knowledge and information in their decision-making (Martin-Clouarie, 2017), hence information needs identification is considered a pre-requisite for the initiation or development of interventions using information systems. Ikwuakam, lyela and Sangotegba (2016) admit the inability of external agents to accurately pinpoint the entire spectrum of information required by smallholder farmers, considering the assortment of novel and complex problems in an information-dependent agricultural environment.

The low acquisition of agricultural information among smallholder farmers lead to poor adoption of improved inputs and technologies, resulting in low levels of productivity (Freeman and Qin, 2020). In line with this, Mukasa, Woldemichael, Salami and Simpasa (2017) averred that the paucity of useful market information, among others, remains a challenge which contributes to the slow pace of agricultural transformation in sub-Sahara Africa.

Information need is a concept variously utilized or embedded in the research concerning information seeking behaviour. It might be construed in the sense of a stream of data, words or figures which enables a recipient to make appropriate decisions. Though there are issues of different terminologies in its definition, information need finds usage in various disciplines and contexts (Afzal, 2017), and is concerned with searching for choices to satisfy an individuals' requirement. The concept of information need is undoubtedly difficult to define, and without any universally agreed means of measurement (Bopape, Dikotla, Mahlatji, Ntsala and Makgahlele, 2017); due to this, current research efforts suggest a shift from discreet elements of information systems to an account of human interaction (Tang, 2018).

Information-seeking behaviour is considered as purposive in nature, being a result of the need to satisfy specific objectives (Kundu, 2017). Information-seeking is described as the processes involved when an individual acquires, evaluates and uses information (Kwanya, 2018; Kadir, Johari and Hussin, 2018). This behaviour hence requires interaction with other persons, information sources or systems, and is a fundamental human process which is closely related to learning and problem solving (Shah, 2017). Information-seeking has influenced progress in human civilization and facilitates a sustained, albeit iterative, cycle of social development. The influential work of Case, outlined information seeking behaviour as a behaviour that occurs when an individual is constrained by a problematic situation, for which his or her internal knowledge, belief and model fails to provide direction towards the resolution of the problem (Case and Given, 2016). In this instance, the information 
Creative Commons User License: CC BY-NC-ND

Abstracted by: EBSCOhost, Electronic Journals Service (EJS), Google Scholar, Journal Seek, Scientific Commons,

Food and Agricultural Organization (FAO), CABI and Scopus
Journal of Agricultural Extension

Vol. 24 (3) July, 2020

ISSN(e): 24086851; ISSN(Print); 1119944X

http://journal.aesonnigeria.org

http://www.ajol.info/index.php/jae

Email: editorinchief@aesonnigeria.org

seeker having the objective to surmount the constraint, proactively searches for information to achieve the desired goal.

It is however, a complex activity requiring different methods influenced by a variety of factors and access to diverse information resources to deal with the information problem (Azadeh and Ghasemi, 2015). Information-seeking behaviour therefore is considered as a set of strategies for locating information by Gordon, Meindl, White and Szigeti (2018), and consists of three core elements of people, information and systems (Garg, 2016). It is a function of the recognition of a need for information, and ability to utilize accessible information resources to meet the identified information need (Uzuegbu and Naga, 2016). Various theoretical or conceptual frameworks and models in information studies confirm a strong link between information needs and information seeking behaviour (Savolainen, 2017), which Freund (2015) ascribed to continual changes in context from one search to the next. These frameworks or models greatly contribute to our comprehension of individual's reaction when they search for information.

Smallholder farmers are undoubtedly a heterogeneous group (Bitzer, Wennink and Piters, 2016), and require targeted approaches for information to solve production and marketing problems. For extension practitioners, the assessment of farmers' ability to utilize proposed solutions or technologies is a principle determining an applicable approach (Payne, Turner, Rijswijk, McDermott and Wakelin, 2016). The assessment follows a process of finding out key problems and opportunities, including types of information required in order to enhance a responsive service. This approach according to Ritter, Jansen, Roche, Kelton and Adams (2016) enables the adaptation of recommendations to individual farmers' settings. Inadequate understanding of farmer's information needs and their information search strategies may hence result in the failure of agricultural extension interventions (Acheampong et al. 2017).

Ford (2015) contended that research on information behaviour enables improvement in the quality and effectiveness of information provision. An understanding of the information needs and search behaviour of a specific group of farmers according to Sobalaje, Ogunmodede, Oyetola and Nwokeoma (2019), or their expressed needs, will therefore assist in better targeted programs or interventions. Idiake-Ochei, Onemolease and Erie (2016) espoused that the design of appropriate information services depends on understanding the information needs and challenges confronting users when they search for information. There is however, limited literature examining farmers' information seeking behaviour in developing countries (Phiri, Chipeta and Chawinga, 2018), with no documented study of the market information needs and information-seeking behaviour among smallholder livestock 
Creative Commons User License: CC BY-NC-ND

Abstracted by: EBSCOhost, Electronic Journals Service (EJS), Google Scholar, Journal Seek, Scientific Commons,

Food and Agricultural Organization (FAO), CABI and Scopus

http://eoi.citefactor.org/10.11226/v24i3
Journal of Agricultural Extension

Vol. 24 (3) July, 2020

ISSN(e): 24086851; ISSN(Print); 1119944X

http://journal.aesonnigeria.org

http://www.ajol.info/index.php/iae

Email: editorinchief@aesonnigeria.org

farmers within the study area. It is this research gap that the present study addressed. The study examined the market information needs and seeking behaviour among smallholder livestock farmers. Specifically, the study:

- identified the market information needs of smallholder livestock farmers.

- explored the information-seeking behaviour among smallholder livestock farmers, and

- investigated the relationship between respondents' demographic characteristics and information-seeking behaviour.

\section{Methodology}

The Eastern Cape province is located in the south-eastern part of South Africa, noted as the second largest province by surface area, and lies between latitude $32.2968^{\circ}$ South and longitude $26.4194^{\circ}$ East. It covers approximately 170,000 square kilometres, which comprise approximately fourteen percent of the total land mass in South Africa. The Eastern Cape Province shown in Figure 1, has the highest number of livestock in South Africa (DAFF, 2017), is bordered by the Western Cape, Northern Cape, Free State and Kwa-Zulu Natal provinces, and also shares a boundary with Lesotho.

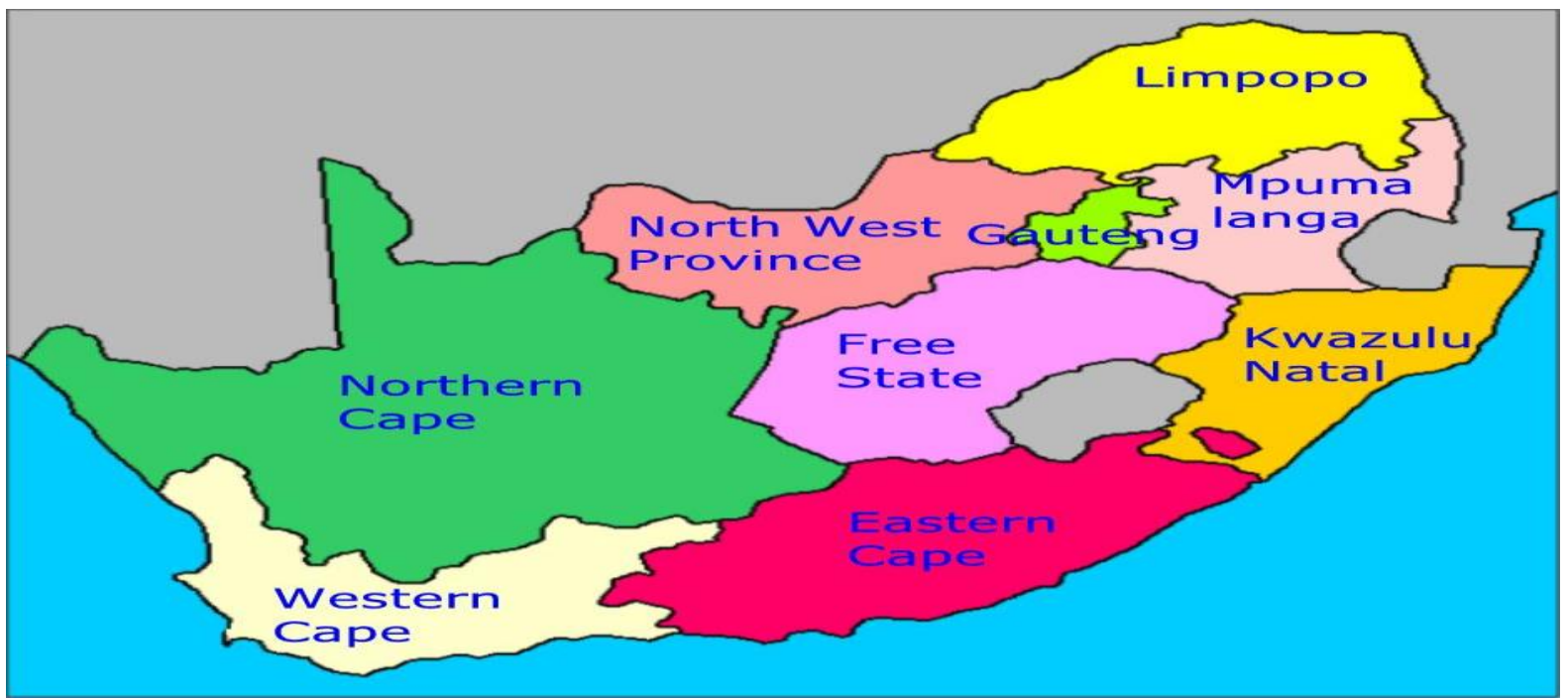

Figure 1: Map of South Africa showing the different provinces.

The Eastern Cape province consists of six district municipalities, including the Alfred Nzo, Oliver Tambo, Amathole, Chris Hani, Sarah Barthman and Joe Qhabi districts. From these district municipalities, the Alfred Nzo district was purposively chosen for this study based on an on-going livestock development intervention by the Department of Rural Development and Agrarian Reform in the district. The study 
Creative Commons User License: CC BY-NC-ND

Abstracted by: EBSCOhost, Electronic Journals Service (EJS), Google Scholar, Journal Seek, Scientific Commons,

Food and Agricultural Organization (FAO), CABI and Scopus
Journal of Agricultural Extension

Vol. 24 (3) July, 2020

ISSN(e): 24086851; ISSN(Print); 1119944X

http://journal.aesonnigeria.org

http://www.ajol.info/index.php/jae

Email: editorinchief@aesonnigeria.org

sample was based on an existing database of livestock farmers with the Department of Rural Development and Agrarian Reform (DRDAR), participating in the Red Meat Development Project. Structured questionnaires were used to collect information from respondents in three local municipalities (Mbizana, Ntanbankulu and Umzimvubu) which were purposively selected due to the large number of registered livestock farmers from these areas. A total of 150 smallholder livestock farmers were selected using a non-random snowballing technique. In arriving at this sample size, available resources and size of area to be covered were a relevant factor. Other considerations taken were the acceptable precision required, level of risk and homogeneity among the population (Taherdoost, 2017), with an error margin of $5 \%$.

To depict respondents' information needs, a list of possible information requirements identified in the literature was included in the questionnaire and the respondents were asked to identify information considered as important, required urgently and the level of need, which were then ranked. A weighted means for each identified information need was calculated and utilised for ranking respondents need. Respondents were also requested to identify the source(s) of information they frequently used, considered as a suitable proxy for information-seeking behaviour. These identified sources were then collated using frequency counts and percentages. The association between respondents' demographic features and their information-seeking behaviour was explored using Pearson's chi-square tests. The test indicates existence of relationship or not, between the dependent and different discrete independent variables. Furthermore, the Product Moment Correlation analysis was used to ensure absence of correlation among the independent variables.

\section{Results and Discussion}

\section{Market Information Needs}

Figure 2 provides a graphic analysis of the data collected. For each identified market information need, there are multiple responses as all respondents contributed towards the score for each identified need. Among all the respondents, information related to dates and venues for livestock auctions was identified by $77 \%$ as mostly needed, while $71 \%$ of respondents acknowledged the cost of transporting livestock to markets as a specific area of information need. 
Creative Commons User License: CC BY-NC-ND

Abstracted by: EBSCOhost, Electronic Journals Service (EJS), Google Scholar, Journal Seek, Scientific Commons,

Food and Agricultural Organization (FAO), CABI and Scopus

http://eoi.citefactor.org/10.11226/v24i3
Journal of Agricultural Extension

Vol. 24 (3) July, 2020

ISSN(e): 24086851; ISSN(Print); 1119944X

http://journal.aesonnigeria.org

http://www.ajol.info/index.php/jae

Email: editorinchief@aesonnigeria.org

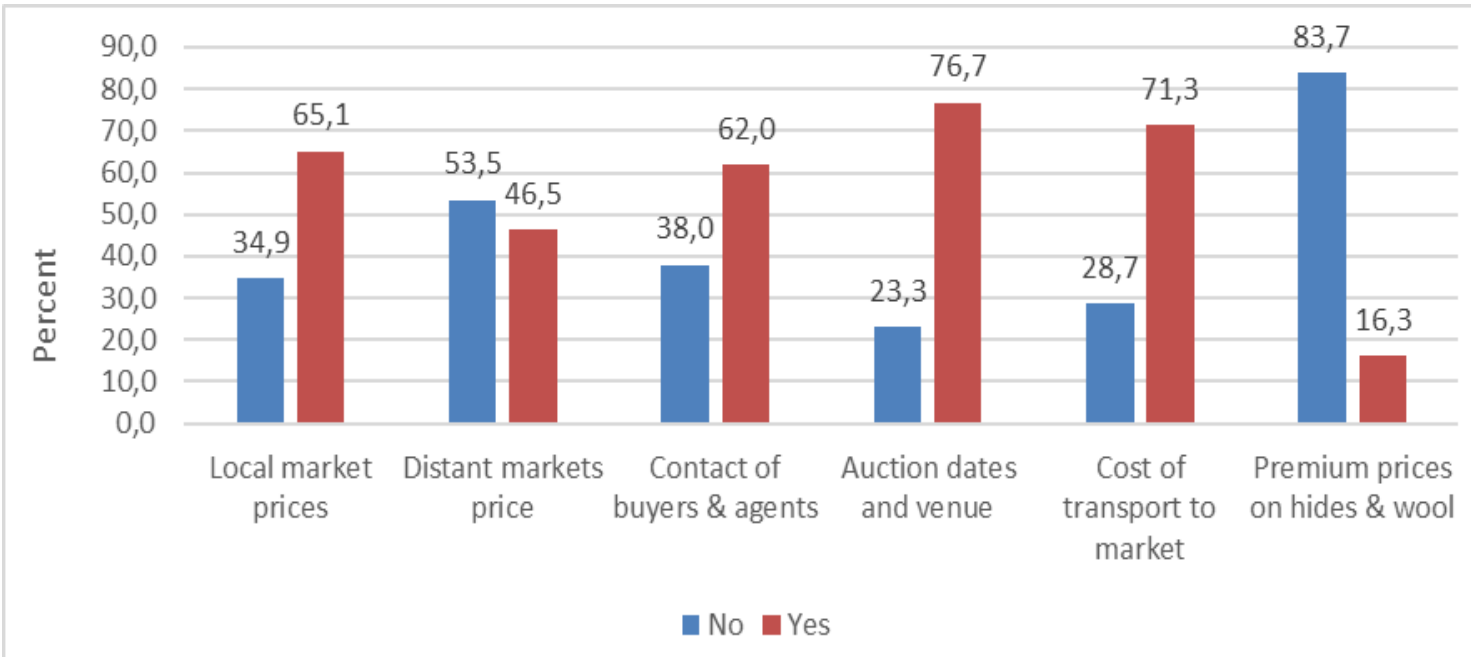

Figure 2: Type of market information need

Local market price of livestock was identified by $65 \%$ of respondents as needed, and $46 \%$ of respondents identified market prices in other distant markets as important. The contact detail of livestock buyers or agents was identified as information needed by $62 \%$ of respondents, and the premium paid on hides and wool which was identified as important by just $16 \%$ of respondents. Information on auction dates and venue, cost of transport to market, local market prices, contact details of buyers and agents, distant markets prices and premium prices on hides and wool were considered accordingly.

Within rural communities where livestock farming is a major livelihood activity, auctions are both a social and commercial event, through which farmers receive price and marketing information (Mbatha, 2019). Ndoro, Mudhara, Chimonyo and Hitayezu (2015) reported auctions to be highly institutionalized livestock marketing outlets in South Africa where farmers purchase or sell livestock, meet with other farmers, livestock buyers, as well as extension officers. At these events, farmers also receive information on livestock health, and are able to purchase medication and supplements for their animals. Attendance at livestock auctions is an opportunity for farmers to build social capital through networking, and considered a lucrative marketing channel among farmers by Ngarava, Phetshe and Mushunje (2019).

Also, many farmers depend on local transporters to send their livestock to markets (Khapayi and Celliers, 2016), which requires constant negotiations and update to enable agreement on transport costs when planning sales or purchases of livestock. Courtois and Subervie (2014) noted the focus on transportation cost as a determinant of participation in markets by farmers. Transport costs significantly influence farmer's market preference as it contributes to their cost of transaction 
Creative Commons User License: CC BY-NC-ND

Abstracted by: EBSCOhost, Electronic Journals Service (EJS), Google Scholar, Journal Seek, Scientific Commons,

Food and Agricultural Organization (FAO), CABI and Scopus

http://eoi.citefactor.org/10.11226/v24i3
Journal of Agricultural Extension

Vol. 24 (3) July, 2020

ISSN(e): 24086851; ISSN(Print); 1119944X

http://journal.aesonnigeria.org

http://www.ajol.info/index.php/jae

Email: editorinchief@aesonnigeria.org

(Anh and Bokelmann, 2019). Local market and distant market price information were also needed by respondents. Haile, Kalkuhl and Usman (2015) averred that through collection of local market prices as well as prices in distant markets, farmers form their price expectations based on this information. The farmers need for market price information is necessary to reduce asymmetry in their dealings with buyers and other market actors (Mitra, Mookherjee, Torero and Visaria, 2018). Livestock prices obtainable in local markets, compared with that in other distant markets are important for decision making among farmers, wherein cost-benefit decisions regarding attendance at these markets can be made. It also assists farmers decide whether it is beneficial to partake in these markets or sell at the farm-gate to livestock buyers or agents, hence the need for their contact information.

The contact details of livestock buyers and agents was considered an important market information need, and fits the perceived role of middlemen in building social networks for economic outcomes (World Bank, 2015; Herforth, Theuvsen, Vasquez and Wollni, 2015). The role of middlemen in promoting marketing among smallholder farmers is however a contested topic, with some scholars highlighting their important role in connecting farmers with buyers (Abebe, Bijman and Royer, 2016), providing needed market information (UNCTAD, 2015); or their reported exhibition of exploitative attitudes along the marketing chain (Gohain and Singh, 2018). The market information needs of premium prices paid for hides and wool is aligned to the information gathering efforts, specifically in a specialized marketing niche of the smallholder livestock farmer.

\section{Classification of Market Information Needs}

Table 1 shows that information regarding prevailing market price for livestock was considered important by $65 \%$ of respondents, while $18 \%$ regarded information about livestock auctions as important and $17 \%$ of respondents considered the contact details for livestock buyers or agents as important. 
Creative Commons User License: CC BY-NC-ND

Abstracted by: EBSCOhost, Electronic Journals Service (EJS),

Google Scholar, Journal Seek, Scientific Commons,

Food and Agricultural Organization (FAO), CABI and Scopus

http://eoi.citefactor.org/10.11226/v24i3
Journal of Agricultural Extension

Vol. 24 (3) July, 2020

ISSN(e): 24086851; ISSN(Print); 1119944X

http://journal.aesonnigeria.org

http://www.ajol.info/index.php/jae

Email: editorinchief@aesonnigeria.org

Table 1. Categories and levels of information need

\begin{tabular}{c|cc}
\hline Information type \& level of need. & Percent & Ranking \\
\hline (a) Market information considered important & 65 & 1 \\
$\quad$ Information on market prices & 18 & 2 \\
$\quad$ Information on livestock auction & 17 & 3 \\
$\quad$ Information of livestock buyers / agents & & \\
(b) Immediate information required & 38 & 1 \\
$\quad$ Information on market prices & 33 & 2 \\
Information on auction dates / venue & 19 & 3 \\
Information on livestock buyers / agents & 10 & 4 \\
Timing of market programs on Radio / & & \\
TV $\quad$ & 48 & 1 \\
(c) Level of information need & 36 & 2 \\
$\quad$ High & 16 & 3 \\
Ledium & & \\
\hline
\end{tabular}

Source: Field Survey 2017

Information on market prices was an immediate requirement for $38 \%$ of respondents, while information on auction dates and venue (33\%), information on livestock agents or buyers by $(19 \%)$, and timing of market information programs on radio and television $(10 \%)$ was required by respondents respectively. Under the level of need category, $48 \%$ of respondents indicated a high level of information need, while $36 \%$ of respondents had a medium level of information need, and $16 \%$ of respondents indicated a low level of information need. The level of information need reflects the ability to obtain the needed information, and the finding suggests that close to half of respondents (48\%) found it difficult to obtain urgently required information, or in other words, were unable to satisfy their market information need.

\section{Information-Seeking Behaviour of Respondents}

Table 2 shows that $36 \%$ of respondents contacted other farmers in their area, while $24 \%$ of respondents used phone calls to external sources to source for market information. In addition to this, $20 \%$ of respondents listened to the radio for market information, $18 \%$ of respondents relied on livestock auction venues, and $2 \%$ of respondents utilized television as the source for market information. 
Creative Commons User License: CC BY-NC-ND

Abstracted by: EBSCOhost, Electronic Journals Service (EJS), Google Scholar, Journal Seek, Scientific Commons,

Food and Agricultural Organization (FAO), CABI and Scopus

http://eoi.citefactor.org/10.11226/v24i3
Journal of Agricultural Extension

Vol. 24 (3) July, 2020

ISSN(e): 24086851; ISSN(Print); 1119944X

http://journal.aesonnigeria.org

http://www.ajol.info/index.php/jae

Email: editorinchief@aesonnigeria.org

Table 2: Source used to seek market information

\begin{tabular}{ccc}
\hline Market information source & Percent & Rank \\
\hline Other farmers & 36 & 1 \\
Phone calls & 24 & 2 \\
Radio broadcast & 20 & 3 \\
Auction venues & 18 & 4 \\
Television & 2 & 5 \\
\hline
\end{tabular}

Source: Field Survey 2017

Other farmers, relatives and friends were the primary source of information among farmers, and fits with the information seeking channel used by many respondents in this study. Acheampong et al. (2017), Msoffe and Ngulube (2016) and Rodriguez, Kulpavaropas, Annamalai, Wright, and Evans (2015), reported the importance of these inter-personal sources of information among smallholder farmers. Farmers tend to seek out other farmers, or their social referents and peers (Ritter et al., 2016), when faced with an information need. According to Brhane, Mammo and Negusse (2017), when the information need is unmet, farmers tend to contact more distant or second level sources such as livestock agents and extension officers. Radio broadcasts, television programs and livestock auction venues are also channels used to obtain market information among respondents. However, only a few respondents considered using television as a market information source, and Uzuegbu (2016) also acknowledged the low usage of television as an information source among rural farmers. Various studies have reported varying levels of interest among farmers in using mass media such as radio and television when seeking information (Kughur, lornenge and Vihi, 2016; Mtega, 2018).

Caffaro, Cremasco, Roccato and Cavallo (2020), and Vishnu, Gupta and Subash (2019), stated that content, source of the information and perceived usefulness, contributed to determining farmers' search behaviour. In their search for localized information related to the livestock enterprise, the farmers' interpersonal sources are the most likely used medium.

\section{Factors Influencing Information-Seeking Behaviour}

Table 3 shows that the independent variables such as respondent's sex $\left(x^{2}=15.61\right)$, age $\left(x^{2}=16.17\right)$, education $\left(x^{2}=50.00\right)$, marital status $\left(x^{2}=34.73\right)$, size of household $\left(x^{2}=43.29\right)$, income $\left(x^{2}=33.16\right)$ and herd size $\left(x^{2}=35.38\right)$ all had a significant 
Creative Commons User License: CC BY-NC-ND

Abstracted by: EBSCOhost, Electronic Journals Service (EJS), Google Scholar, Journal Seek, Scientific Commons,

Food and Agricultural Organization (FAO), CABI and Scopus

http://eoi.citefactor.org/10.11226/v24i3
Journal of Agricultural Extension

Vol. 24 (3) July, 2020

ISSN(e): 24086851; ISSN(Print); 1119944X

http://journal.aesonnigeria.org

http://www.ajol.info/index.php/jae

Email: editorinchief@aesonnigeria.org

association with the dependent variable. Most of the personal factors showed a significant influence with a $p$-value $\leq 0.01$. This implies that any change in the independent variables (personal characteristics of the respondents) had an effect on, or influenced the dependent variable (information seeking behaviour). The analysis indicates that personal characteristics strongly influenced farmers' information seeking behaviour.

Table 3: Variables influencing information-seeking behaviour

\begin{tabular}{llll}
\hline Characteristics & Value $\left(X^{2}\right)$ & DF & Sig. \\
\hline Sex & $15.615^{*}$ & 4 & $0.004^{*}$ \\
Age & $16.176^{* *}$ & 8 & $0.040^{* *}$ \\
Education & $50.003^{*}$ & 12 & $0.000^{*}$ \\
Marital status & $34.738^{*}$ & 12 & $0.001^{*}$ \\
Household size & $43.294^{*}$ & 8 & $0.000^{\star}$ \\
Income & $33.168^{*}$ & 4 & $0.000^{*}$ \\
Herd size & $35.387^{*}$ & 12 & $0.000^{\star}$ \\
\hline
\end{tabular}

${ }^{*} \mathrm{P} \leq 0.01,{ }^{*} \mathrm{P} \leq 0.05 \quad$ Source: Field Survey 2017.

Other studies have also reported differences in information seeking behaviour among male and female farmers. Chatterjee and Dasgupta (2016) observed that farmers' sex plays a significant role in information seeking behaviour, while Sharma and Maheshwari (2015) noted the growing evidence of women utilizing ICTs for information search. Said-Allsop and Tallontire (2015) asserted that the availability of ICTs for information search could be an opportunity for making choices available, which Nagothu, Kolberg and Stirling (2016) considered to be critical for addressing issues affecting women in agriculture.

Age of respondents also influenced their information-seeking behaviour from this study, and is similar to the findings by Lwoga, Nagu and Sife (2017) as well as Idiake-Ochei et al. (2017). In the study by Lwoga et al. (2017), age moderated the usage of internet sources in the search for health information among respondents. Younger farmers were reported to utilize ICTs such as mobile phones and internetenabled computers, more than older farmers by Lokeswari (2016). Older farmers have also been observed by Idiake-Ochei et al. (2017) to rely more on their experience and hence limited their search for information, while younger farmers had the required energy and enthusiasm to seek information. These reports establish the significant effect of age on information-seeking behaviour. 
Creative Commons User License: CC BY-NC-ND

Abstracted by: EBSCOhost, Electronic Journals Service (EJS), Google Scholar, Journal Seek, Scientific Commons,

Food and Agricultural Organization (FAO), CABI and Scopus
Journal of Agricultural Extension

Vol. 24 (3) July, 2020

ISSN(e): 24086851; ISSN(Print); 1119944X

http://journal.aesonnigeria.org

http://www.ajol.info/index.php/jae

Email: editorinchief@aesonnigeria.org

Education and information seeking behaviour also have a significant relationship, which has been reported by Ezeh and Ezeh (2017) where they concluded that education improved innovative outlook and positive attitudes. Higher levels of education were linked to increased awareness and capacity among farmers, to test and utilize additional information sources which invariably influenced their information-seeking behaviour. Marital status as an independent variable, had a significant effect on information seeking behaviour of respondents in the survey. Nwagwu and lgwe (2015) had noted a similar result, where married respondents in their study reported seeking more information than unmarried respondents.

Household size significantly influenced the information seeking behaviour of respondents. More persons in a household is expected to translate into more requirements for information, hence larger households were more pro-active in searching for relevant information and Ezeh et al. (2017) reported household size to significantly influence information-seeking behaviour. An additional income source was also found to be significant in this study, and has been reported to increase information searching, as the capacity to access and apply information was considered greater among those with an income by Nangsangna and Vroom (2019). Herd size owned by the survey respondents showed significant association with information-seeking behaviour. This finding is similar to that reported by Triveni, Sharma, Satyanarayana, Rao and Raghunandhan (2018), where herd size was found to have a positive and significant influence on dairy farmers' knowledge levels. Increased herd size in their view, encouraged livestock farmers to seek additional information regarding health and market issues, which is an indication of its effect on information-seeking behaviour.

Various studies have reported the effect of different factors on information-seeking behaviour (Azadeh and Ghasemi, 2015; Brhane et al., 2017; Chen and Lu, 2019; Ochei-Idiake et al., 2016; Waqas, Khan, Nosheen and Ahmad, 2015). Chen and Lu (2019) outlined how individual, social and family characteristics influenced information needs and access channel preferences. Brhane et al. (2017) also reported that information seeking behaviour was affected by a variety of factors ranging from geographic location, economic status, to demographic characteristics, psychological and institutional factors. Waqas et al. (2015) further acknowledged that different socio-economic factors among farmers influenced the information sources used. Among extension personnel studied by Ochei-ldiake et al. (2016), key personal features were found to influence their information-seeking behaviour; while Nwafor (2020) averred that the personal characteristics of farmers accounted for many of their ICT-source adoption attributes. Different methods used to search for information are influenced by diverse factors (Azadeh and Ghasemi, 2015), and therefore different variables affect information seeking in different ways. These 
Creative Commons User License: CC BY-NC-ND

Abstracted by: EBSCOhost, Electronic Journals Service (EJS), Google Scholar, Journal Seek, Scientific Commons,

Food and Agricultural Organization (FAO), CABI and Scopus

http://eoi.citefactor.org/10.11226/v24i3
Journal of Agricultural Extension

Vol. 24 (3) July, 2020

ISSN(e): 24086851; ISSN(Print); 1119944X

http://journal.aesonnigeria.org

http://www.ajol.info/index.php/jae

Email: editorinchief@aesonnigeria.org

corroborate and lend credence to findings from this study, indicating the influence of identified demographic variables on information-seeking behaviour of smallholder livestock farmers within the study area.

\section{Conclusion and Recommendation}

Smallholder livestock farmers require information such as auction venues and dates, contacts of livestock buyers or agents, and price offered in different markets. Among these information needs, the current price offered for livestock in local and other markets was found to be regarded as most important.

In searching for information, inter-personal sources such as family, friends, and other farmers were initial sources consulted by smallholder livestock farmers. Mobile phones were used to seek additional information from agents, extension officials or other distant sources. Radio and attendance at auctions are also a means for getting market information by livestock farmers. The personal characteristics such as age, sex, education, marital status, household and herd sizes, significantly influenced information-seeking behaviour of the farmers.

There is a need to increase the information available to farmers, which can be achieved by utilizing existing and new avenues, such as extension officers and ICTenabled channels. Any planned use of various information channels should consider age, sex of the farmer, level of education, social factors and income differences, including access to communication channels among the smallholder livestock farmers. This needs to specifically direct information flow to benefit smallholder livestock farmers in rural communities, this will involve a reconfiguration of the role played by government and its agencies in improving access to market-related information.

\section{References}

Abebe, G.K., Bijman, J., \& Royer, A. (2016). Are middlemen facilitators or barriers to improve smallholders' welfare in rural economies? Empirical evidence from Ethiopia. Journal of Rural Studies, 43(1), 203-213.

Acheampong, D.L., Frimpong, B.N., Adu-Appiah, A., Asante, B.O., \& Asante, M.D. (2017). Assessing the information seeking behaviour and utilization of rice farmers in the Ejisu-Juaben municipality of Ashanti Region, Ghana. Agriculture and Food Security, 6(1), 38-47.

Afzal, W. (2017). Conceptualization and measurement of information Needs: A literature review. Journal of the Australian Library and Information Association, 66(2), 116 138. 
Creative Commons User License: CC BY-NC-ND

Abstracted by: EBSCOhost, Electronic Journals Service (EJS), Google Scholar, Journal Seek, Scientific Commons,

Food and Agricultural Organization (FAO), CABI and Scopus

http://eoi.citefactor.org/10.11226/v24i3
Journal of Agricultural Extension

Vol. 24 (3) July, 2020

ISSN(e): 24086851; ISSN(Print); 1119944X

http://journal.aesonnigeria.org

http://www.ajol.info/index.php/jae

Email: editorinchief@aesonnigeria.org

Anh, N.H., \& Bokelmann, W. (2019). Determinants of smallholders' market preferences: The case of sustainable certified coffee farmers in Vietnam. Sustainability 2019(11), doi:10.3390/su11102897.

Azadeh, F., \& Ghasemi, S. (2015). Investigating Information-Seeking Behaviour of Faculty Members Based on Wilson's Model: Case Study of PNU University, Mazandaran, Iran. Global Journal of Health Science, 8(9), 26-36.

Bitzer, V., Wennink, B., \& Piters, B.S. (2016). The Governance of Agricultural Extension Systems. KIT Working Papers 2016-01.

Bopape. S., Dikotla, M, Mahlatji, M., Ntsala, M., \& Makgahlela, L. (2017). Identifying the information needs of public library and information services users in Limpopo Province. South African Journal of Library \& Information Science, 83(1), 1-10.

Brhane, G., Mammo, Y., \& Negusse, G. (2017). Sources of information and information seeking behaviour of smallholder farmers in Tanqa Abergelle Wereda, Central Zone of Tigray, Ethiopia. Journal of Agricultural Extension and Rural Development, 9(4), 47 -52 .

Caffaro, F., Cremasco, M.M., Roccato, M., \& Cavallo, E. (2020). Drivers of farmers' intention to adopt technological innovations in Italy: The role of information sources, perceived usefulness and perceived ease of use. Journal of Rural Studies, (in-press). Retrieved from https://doi.org/10.1016/j.jrurstud.2020.04.028.

Case, D.O., \& Given, L.M. (2016). Looking for Information: A Survey of Research on Information Seeking, Needs and Behaviour, 4th Edition, Emerald Group Publishing Limited, Amsterdam.

Chatterjee, K., \& Dasgupta, S. (2016). Literature review of information seeking behaviour of farmers in India. International Journal of Humanities and Social Sciences, 5(5), 161180.

Chen, Y., \& Lu, Y. (2019). Factors influencing the information needs and information access channels of farmers: An empirical study in Guangdong, China. Journal of Information Science, 46(1), 3-22.

Department of Agriculture, Forestry \& Fisheries. (2017). National Livestock Statistics. National Department of Agriculture, Pretoria, South Africa.

Ezeh, C.C., \& Ezeh, O.H. (2017). Perception and information seeking behaviour of rural households towards health promoting practices in Maigana District of Kaduna State, Nigeria. Open Journal of Medical Psychology, 6(4), 233-242.

Ford, N. (2015), Introduction to Information Behaviour. Facet Publishers. London. 
Creative Commons User License: CC BY-NC-ND

Abstracted by: EBSCOhost, Electronic Journals Service (EJS), Google Scholar, Journal Seek, Scientific Commons,

Food and Agricultural Organization (FAO), CABI and Scopus

http://eoi.citefactor.org/10.11226/v24i3
Journal of Agricultural Extension

Vol. 24 (3) July, 2020

ISSN(e): 24086851; ISSN(Print); 1119944X

http://journal.aesonnigeria.org

http://www.ajol.info/index.php/jae

Email: editorinchief@aesonnigeria.org

Freeman, K., \& Qin, H. (2020). The role of information and interaction processes in the adoption of agricultural inputs in Uganda. Agronomy, 10(202), doi:10.3390/agronomy10020202.

Freund, L. (2015). Contextualising the information-seeking behaviour of software engineers. Journal of the Association for Information Science and Technology, 66(8), 1594-1608.

Gamble, K.R., Cassenti, D.N., \& Buchler, N. (2018). Effects of information accuracy and volume on decision-making. Military Psychology, 30(4), 311-320.

Garg, M. (2016). Information seeking behaviour models: A brief introduction. International Journal of Library and Information Studies, 6(1), 161-168.

Garrido, M., \& Wyber, S. (2017). Development and Access to Information. International Federation of Library Associations and Institutions. The Hague. Retrieved from https://da2i.ifla.org/wp-content/uploads/da2i-2017-full-report.pdf .

Gohain, N., \& Singh, S. (2018). An analysis of problems and constraints faced by farmers in marketing of agricultural produce in Punjab. Economic Affairs, 63(3), 671-678.

Gordon, I.D., Meindl, P., White, M., \& Szigeti, K. (2018). Information seeking behaviours, attitudes, and choices of academic chemists. Science and Technology Libraries, 37(2), 130-151.

Haile, M.G., Kalkuhl, M., \& Usman, M.A. (2015). Market information and smallholder farmer price expectation. African Journal of Agricultural and Resource Economics, 10(4), 297-311.

Herforth, N., Theuvsen, L., Vasquez, W., \& Wollni, M. (2015). Understanding Participation in Modern Supply Chains Under a Social Network Perspective- Evidence from Blackberry Farmers in the Ecuadorian Andes. Global Food Discussion Papers, No. 57. Gottingen, Germany.

Idiake-Ochei, O., Onemolease, E.A., \& Erie, G.O. (2016). Information-seeking behaviour of extension personnel in Edo State, Nigeria. Scholars Journal of Agriculture and Veterinary Sciences, 3(4), 318-325.

Ikwuakam, O.T., Iyela, A., \& Sangotegba, N.S. (2016). Information needs of sesame farming households in selected agricultural zones of Katsina State, Nigeria. Mediterranean Journal of Social Sciences, 7(1), 204-212.

Kadir, M.R., Johari, N.I., \& Hussin, N. (2018). Information needs and information seeking behaviour: A case study on students in private university library. International Journal of Academic Research in Progressive Education and Development, 7(3): 226-235.

Khapayi, M., \& Celliers, P.R. (2016). Factors limiting and preventing emerging farmers to progress to commercial agricultural farming in the King William's Town area of the 
Creative Commons User License: CC BY-NC-ND

Abstracted by: EBSCOhost, Electronic Journals Service (EJS), Google Scholar, Journal Seek, Scientific Commons,

Food and Agricultural Organization (FAO), CABI and Scopus

http://eoi.citefactor.org/10.11226/v24i3
Journal of Agricultural Extension

Vol. 24 (3) July, 2020

ISSN(e): 24086851; ISSN(Print); 1119944X

http://journal.aesonnigeria.org

http://www.ajol.info/index.php/jae

Email: editorinchief@aesonnigeria.org

Eastern Cape Province, South Africa. South African Journal of Agricultural Extension, 44(1), 25-41.

Kughur, P.G., lornenge, G.M., \& Vihi, S.K. (2016). Assessment of radio and television role in agricultural information transfer among farmers in Katsina-Ala Local Government Area of Benue State, Nigeria. FUW Trends in Science and Technology Journal, 1(2), 442-447.

Kundu, D.K. (2017). Models of information seeking behaviour: A comparative study. International Journal of Library and Information Studies, 7(4), 393-405.

Kwanya, T. (2018). Information Seeking Behaviour in Digital Library Contexts. In: Library Science and Administration: Concepts, Methodologies, Tools and Applications. IGI Global Publishers. DOI: 10.4018/978-1-5225-3914-8.ch066.

Lokeswari, K. (2016). A study of the use of ICTs among rural farmers. International Journal of Communication Research, 6(3), 232-238.

Lwoga, E.T., Nagu, T., \& Sife, A.S. (2017). Online information seeking behaviour among people living with HIV in selected public hospitals of Tanzania. Journal of Systems and Information Technology, 19(1), 94-115.

Martin-Clouarie, R. (2017). Modelling operational decision-making in agriculture. Agricultural Sciences, 2017(8), 527-544.

Mbatha, C.N. (2019). Livestock Markets for Small Emerging Farmers in South Africa: Comparative Lessons from Uasin-Gishu in Kenya and the Eastern Cape Province in South Africa. Paper presented at the International Atlantic Economic Society Conference. February 2019, Athens-Greece.

Mitra, S., Mookherjee, D., Torero, M., \& Visaria, S. (2018). Asymmetric information and middleman margins: An experiment with Indian Potato Farmer. The Review of Economics and Statistics, 100(1), 1-13.

Msoffe, G.E., \& Ngulube, P. (2016). Information sources preference of poultry farmers in selected rural areas of Tanzania. Journal of Librarianship and Information Science, 49(1), 82-90.

Mtega, W.P. (2018). The usage of radio and television as agricultural knowledge sources: The case of farmers in Morogoro Region of Tanzania. International Journal of Education and Development using Information and Communication Technologies in Developing Countries, 14(3), 252-266.

Mukasa, A.N., Woldemichael, A.D., Salami, A.O., \& Simpasa, A.M. (2017). Africa's Agricultural Transformation: Identifying Priority Areas and Overcoming Challenges. Africa Economic Brief. 8(1). African Development Bank (ADB). 
Creative Commons User License: CC BY-NC-ND

Abstracted by: EBSCOhost, Electronic Journals Service (EJS), Google Scholar, Journal Seek, Scientific Commons,

Food and Agricultural Organization (FAO), CABI and Scopus

http://eoi.citefactor.org/10.11226/v24i3
Journal of Agricultural Extension

Vol. 24 (3) July, 2020

ISSN(e): 24086851; ISSN(Print); 1119944X

http://journal.aesonnigeria.org

http://www.ajol.info/index.php/jae

Email: editorinchief@aesonnigeria.org

Nagothu, U.S., Kolberg, S., \& Stirling, C.M. (2016). Climate Smart Agriculture: Is This the new paradigm of agricultural development? In Nagothu, U.S. (Ed.). Climate Change and Agricultural Development: Improving Resilience Through Climate Smart Agriculture, Agroecology and Conservation (1-20), Oxon: Routledge.

Nangsangna, R.D., \& Vroom, F.D. (2019). Factors influencing online health information seeking behaviour among patients in Kwahu West Municipal, Nkawkaw, Ghana. Online Journal of Public Health Informatics, 11(2), doi: 10.5210/ojphi.v11i2.10141.

Ndoro, J.T., Mudhara, M., Chimonyo, M., \& Hitayezu, P. (2015). Farmers' Choice of Marketing Channels in Rural South Africa: A Transaction Costs Economics Perspective. Conference Paper. 29th International Conference of Agricultural Economists, August 8-14, Milan, Italy.

Ngarava, S., Phetshe, M., \& Mushunje, A. (2019). Market awareness and participation for cattle farmers in the Kaonafatso ya Dikgomo (KyD) Scheme in KwaZulu-Natal Province, South Africa. Agriculture, 9(215), doi:10.3390/agriculture9100215

Nwafor, C.U. (2020). An Integrated Conceptual Framework for ICT-based Information Source Adoption among Smallholder Farmers. doi:10.20944/preprints202003.0163.v1.

Nwagwu, W.E., \& Igwe, E.G. (2015). Safety information-seeking behaviour of artisanal and small-scale miners in selected locations in Nigeria. Libri, 65(1), 71-90.

Payne, T.A., Turner, J.A., Rijswijk, K., McDermott, A.K., \& Wakelin, R.D. (2016). Informing extension project design: The right tool for the job. Grassland Research and Practice Series, 16(2016), 33-38.

Phiri, A., Chipeta, G.T., \& Chawinga, W.D. (2018). Information behaviour of rural smallholder farmers in selected developing countries: A literature review. Information Development, 35(5), 831-838.

Ritter, C., Jansen, J., Roche, S., Kelton, D.F., \& Adams, C.L. (2016). Determinants of farmers adoption of management-based strategies for infectious disease prevention and control. Journal of Dairy Science, 100(5), 3329-3347.

Rodriguez, L., Kulpavaropas, S., Annamalai, D., Wright, J., \& Evans, J.F. (2015). Trends in Information Needs and Communication Channel Use Among Rural Women in Africa, Asia and Latin America, 2000-2012. Journal of Agriculture and Food Information, 16(3), 221-241.

Said-Allsopp, M., \& Tallontire, A. (2015). Pathways to empowerment? Dynamics of women's participation in global value chains. Journal of Cleaner Production, 107(1), 114-121. 
Creative Commons User License: CC BY-NC-ND

Abstracted by: EBSCOhost, Electronic Journals Service (EJS), Google Scholar, Journal Seek, Scientific Commons,

Food and Agricultural Organization (FAO), CABI and Scopus

http://eoi.citefactor.org/10.11226/v24i3
Journal of Agricultural Extension

Vol. 24 (3) July, 2020

ISSN(e): 24086851; ISSN(Print); 1119944X

http://journal.aesonnigeria.org

http://www.ajol.info/index.php/iae

Email: editorinchief@aesonnigeria.org

Savolainen, R. (2017., Information need as trigger and driver of information seeking: A conceptual analysis, Aslib Journal of Information Management, 69(1), 2-21.

Shah, C. (2017). Information Seeking. In: Social Information Seeking. The Information Retrieval Series, 38(1), 13-27. Springer, Cham.

Sharma, S., \& Maheshwari, S. (2015). Use of ICT by farm women: A step towards empowerment. Indian Research Journal of Extension Education, 15(3), 60-65.

Sobalaje, A.J., Ogunmodede, T.A., Oyetola, S.O., \& Nwokeoma, M.N. (2019). Information Needs, Information Sources and Information Seeking Behaviour of Extension Workers in Osogbo Zone of Osun State, Nigeria. Library Philosophy and Practice (e-journal). Retrieved from https://digitalcommons.unl.edu/libphilprac/3031.

Taherdoost, H. (2017). Determining sample size: How to calculate survey sample size. International Journal of Economics and Management Systems, 2 (1), 236-239.

Tang, R. (2018). Information Behaviour Research in Need of Paradigm Shift. SIG Use Symposium Presentation. Simmons University. Retrieved from https://siguse.files.wordpress.com/2018/11/2018-rong-tang.pdf .

Triveni, G., Sharma, G.K., Satyanarayana, C., Rao, K.S., \& Raghunandhan, T. (2018). Knowledge level of dairy farmers on adoption of dairy innovations in Andhra-Pradesh: An Analysis. Indian Research Journal of Extension Education, 18(1), 1-4.

United Nations Conference on Trade and Development. (2015). Commodities and Development Report 2015: Smallholder Farmers and Sustainable Commodity Development. UNCTAD.

Uzuegbu, C. P. (2016), Effective information service delivery to rural dwellers in SubSaharan Africa: whose job? IFLA Journal, 42(1), 49-58

Uzuegbu, C.P., \& Naga, M.M. (2016). Information communication to rural cassava farmers in Nigeria: A pilot study. Journal of Applied Information Science and Technology, 9(2): 120-132.

Vishnu, S., Gupta, J., \& Subash, S.P. (2019). Social network structures among the livestock farmers vis a vis calcium supplement technology. Information Processing in Agriculture, 6(1), 170-182.

World Bank. (2015). World Development Report: Mind, Society and Behaviour. The World Bank, Washington, DC. 